\title{
ANALISIS PERILAKU KONSUMEN DALAM KEPUTUSAN PEMBELIAN ONLINE SEBELUM DAN SELAMA PANDEMI COVID-19 STUDI KASUS PADA PENGGUNA APLIKASI SHOPEE DI KOTA MAKASSAR
}

\author{
HERNIAH S, NORMIYATI N \\ Fakultas Ekonomi dan Bisnis Universitas Pejuang Republik Indonesia \\ e-mail : erni81syam@gmail.com
}

\begin{abstract}
ABSTRAK
Penelitian ini bertujuan untuk mengetahui perbedaan antara perilaku konsumen sebelum dan selama pandemi Covid-19 serta keputusan pembelian online sebelum dan selama pandemi Covid-19. Jenis penelitian ini adalah penelitian kuantitatif dangan menggunakan pendekatan komparatif. Sampel yang diambil sebanyak 100 pengguna aplikasi Shopee di kota Makassar. Adapun teknik penentuan sampel yang akan dilakukan dalam penelitian ini bersifat tidak acak (non-random sampling) yaitu dengan menggunakan teknik purposive sampling. Hasil Penelitian ini menggunakan analisis komparatif dan memperoleh hasil bahwa terdapat perbedaan antara perilaku konsumen dalam pembelian sebelum dan selama pandemi Covid-19 pada pengguna aplikasi Shopee di kota Makassar, serta di dapatkan hasil bahwa tidak ditemukan perbedaan keputusan pembelian online sebelum dan selama pandemi Covid-19 pada pengguna aplikasi ShopeeMakassar.
\end{abstract}

Kata Kunci : Perilaku Konsumen, Keputusan Pembelian, Pandemi Covid-19

ABSTRACT

This research aimed to determine the differences between consumer behavior before and during the pandemic of Covid-19 as well as online purchasing decisions before and during the pandemic of Covid-19. The type of this research was quantitative by using a comparative approach. The samples of this research were 100 users of Shopee application in the Makassar. The technique of sampling in this research was used non-random sampling, namely by using purposive sampling technique. The results of this research used comparative analysis and obtain the results that there were differences between consumer behavior in purchasing before and during the pandemic of Covid-19 on Shopee application users in the Makassar, and the results showed that there were no differences in online purchasing decisions before and during the pandemic of Covid-19 on Shopee application users in Makassar.

Keywords: Consumer Behavior, Purchase Decision, Pandemic of Covid-19

\section{PENDAHULUAN}

Situasi Pandemi Covid-19 yang sedang terjadi seperti sekarang ini, tentunya telah berpengaruh besar terhadap berbagai aspek kehidupan dimasyarakat, akibat pandemi Covid-19 pemerintah harus mengambil beberapa kebijakan, salah satunya adalah dengan menerapkan pemberlakuan PSBB (Pembatasan Sosial Berskala Besar). Hal tersebut tentu membuat sebagian besar orang harus melakukan kegiatan sehari-hari dari rumah, para karyawan mengerjakan pekerjaan dari rumah dan tak sedikit para pekerja pada perusahaan yang harus dirumahkan bahkan harus terkena PHK, para pelajar/mahasiswa juga harus melakukan kegiatan pembelajaran dari rumah. Pengaruh dari adanya situasi pandemi Covid-19 ini bukan hanya terasa dari sisi pekerjaan atau belajar saja, tetapi juga berpengaruh besar terhadap masyarakat luas dalam peranannya sebagai konsumen.

Menurut Firmansyah (2012) perilaku konsumen di defenisikan sebagai proses yang terkait erat dengan keberadaan proses pembelian, selama waktu orang itu mencari, menyelidiki dan mengevaluasi barang dan jasa sedangkan keputusan pembelian merupakan salah satu rangkaian dari perilaku konsumen yang mendefinisikan proses pengambilan keputusan untuk 
membeli barang atau jasa di mana orang-orang terlibat langsung dalam pembelian dan penggunaan barang atau jasa tersebut. Kotler (2013)

Seorang konsumen di dalam mengambil sebuah keputusan untuk membeli, maka konsumen tersebut akan menjumpai serangkaian proses keputusan yang dimana terdiri dari tujuh aspek, adapun ketujuh aspek keputusan pembelian tersebut menurut Swastha dan Irawan (2013) adalah sebagai berikut:

a. Jenis produk adalah produk yang dijual perusahaan dengan beraneka ragam yang telah sesuai dengan apa yang diinginkan oleh para konsumen.

b. Bentuk produk merupakan kondisi dari produk yang dijual oleh suatu perusahaan.

c. Merek adalah produk yang dijual perusahaan merupakan merek yang ternama dan terkenal di masyarakat.

d. Penjual adalah individu maupun organisasi yang bertugas untuk melayani konsumen memberikan pelayanan yang menyenangkan dengan memberikan perhatian kepada minat konsumen dan memotivasi konsumen untuk membeli.

e. Jumlah produk adalah berapa banyak produk yang dihasilkan serta yang dijual olehsuatu perusahaan.

f. Waktu pembelian adalah waktu yang dipilih oleh konsumen untuk melakukan proses pembelian suatu produk.

g. Cara pembayaran adalah bagaimana konsumen dapat melakukan pembayaran terhadap produk yang yang dibelinya, yaitu pembayaran yang dilakukan secara tunai maupun non tunai.

Penyebaran Covid-19 secara luas membuat konsumen lebih memperhatikan keperluan yang akan dibelinya, rata-rata konsumen mengurangi pengeluarannya dalam melakukan kegiatan pembelian kecuali yang menyangkut dengan kebutuhan rumah tangga seperti bahan pokok dan alat kesehatan, dalam data berikut ini dapat kita lihat mengenai perkembangan konsumsi masyarakat di kota Makassar dari 2016 hingga tahun 2020, yang dimana pada tahun 2020 merupakan awal mula penyebaran Covid-19 di Indonesia.

Tabel 1. Perkembangan Konsumsi Rumah Tangga Di Kota Makassar Tahun 2016-2020

\begin{tabular}{|l|c|c|c|c|c|}
\hline \multicolumn{1}{|c|}{ Uraian } & 2016 & 2017 & 2018 & 2019 & 2020 \\
\hline $\begin{array}{l}\text { Total konsumsi rumah } \\
\text { tangga }\end{array}$ & & & & & \\
$\begin{array}{l}\text { a. ADHB (Miliar Rp) } \\
\text { b. ADHK 2010 (Miliar Rp) }\end{array}$ & $49.151,94$ & $75.942,20$ & $84.234,32$ & $91,405,35$ & $93.008,00$ \\
\hline Rata-rata konsumsi per- kapita & $52.493,94$ & $55.561,02$ & $58.881,87$ & $58.521,43$ \\
a. ADBH ( Juta Rp) & 47,05 & 51,00 & 55,86 & 59,87 & 60,20 \\
b. ADHK 2010 (Juta Rp) & 33,98 & 35,72 & 37,31 & 39,04 & 37,88 \\
\hline $\begin{array}{l}\text { Pertumbuhan } \\
\text { a. Total konsumsi RT }\end{array}$ & 5,65 & 6,57 & 5,84 & 5,97 & $-0,61$ \\
b. Perkapita & 4,18 & 5,10 & 4,46 & 4,63 & $-2,97$ \\
\hline
\end{tabular}

Sumber : Badan Pusat Statistik kota Makassar, 2021

Pada tabel 1 menggambarkan bahwa pengeluaran konsumsi akhir rumah tangga di Kota Makassar meningkat signifikan antara tahun 2016 dan 2019, baik secara nominal (atas harga berlaku) maupun secara riil (atas harga berlaku) (atas harga konstan). Salah satu faktor yang mendorong peningkatan nilai pengeluaran konsumsi rumah tangga adalah peningkatan jumlah konsumen. Namun, konsumsi akhir rumah tangga diperkirakan turun pada 2020. Hal ini karena pandemi Covid-19 yang menurunkan daya beli masyarakat.

Komponen konsumsi rumah tangga meningkat sebesar 5,65\% pada tahun 2016. Kemudian, 6,57 persen pada tahun 2017; 5,84 persen pada 2018; 5,98 persen pada 2019; dan - 
0,61 persen pada tahun 2020. (2020). Sementara itu, konsumsi per kapita mengalami peningkatan sebesar 4,18 persen pada $2016,5,10$ persen pada 2017, 4,46 persen pada 2018, 4,63 persen pada 2019, dan $-2,97$ persen pada 2020. (2020). Menurut angka-angka ini, pengeluaran rumah tangga "rill" secara keseluruhan diperkirakan akan turun pada tahun 2020. Hal ini disebabkan oleh penurunan daya beli di antara orang-orang selama pandemi.

Dapat dirata-ratakan bahwa konsumsi perkapita di kota Makassar dari tiap tahunnya terus meningkat berdasarkan harga yang berlaku. Di tahun 2016, setiap keluarga di kota Makassar menggelontorkan dana sekitar 47,05 juta Rupiah setiap tahunnya tahun guna memenuhi kebutuhan konsumsinya. Biaya tersebut mengalami kenaikan menjadi sebesar 51,00 Juta Rupiah (2017); 55,86 Juta Rupiah (2018); 59,87 Juta Rupiah (2019); 60,20 Juta Rupiah (2020). Sedangkan, berdasarkan harga konstan (2010) konsumsi rumah tangga di tahun 2020 secara rata-rata mengalami penurunan. Kondisi tersebut menunjukan bahwa rata-rata konsumsi setiap penduduk mengalami peningkatan kuantitas (volume) namun secara nilai (kualitas) mengalami penurunan. Penurunan rata-rata konsumsi rumah tangga di tahun 2020 tersebut tentu berpengaruh pada struktur konsumsi rumah tangga, yang dimana hal tersebut disebabkan karena situasi pandemi covid-19 yang terjadi seperti saat ini, seperti terlihat pada tabel berikut:

Tabel 2. Komponen Konsumsi Masyarakat Di Kota Makassar 2016-2020

\begin{tabular}{|c|l|c|c|c|c|c|}
\hline No & Komponen Konsumsi & 2016 & 2017 & 2018 & 2019 & 2020 \\
\hline 1 & $\begin{array}{l}\text { Makanan, Minuman, } \\
\text { dan Rokok }\end{array}$ & 26,75 & 26,59 & 26,61 & 26,95 & 26,70 \\
\hline 2 & $\begin{array}{l}\text { Pakaian dan Alas } \\
\text { Kaki }\end{array}$ & 6,08 & 6,07 & 5,96 & 6,03 & 5,53 \\
\hline 3 & $\begin{array}{l}\text { Perumahan, Perkakas, } \\
\text { Perlengkapan dan } \\
\text { Penyelenggaraan } \\
\text { Rumah Tangg }\end{array}$ & 11,25 & 11,34 & 10,93 & 10,49 & 11,57 \\
\hline 5 & $\begin{array}{l}\text { Kesehatan dan } \\
\text { Pendidikan }\end{array}$ & 12,58 & 12,51 & 13,11 & 13,11 & 15,10 \\
\hline 5 & $\begin{array}{l}\text { Kransportasi, } \\
\text { Komunikasi, } \\
\text { Rekreasi, dan Budaya }\end{array}$ & 29,18 & 29,45 & 29,47 & 29,94 & 27,57 \\
\hline 7 & Hotel dan Restoran & 8,73 & 8,64 & 8,65 & 8,07 & 7,75 \\
\hline & Lainnya & 5,43 & 5,41 & 5,27 & 5,41 & 5,77 \\
\hline
\end{tabular}

Sumber : Badan Pusat Statistik kota Makassar, 2021

Terkait perilaku konsumen dan keputusan pembelian di masa pandemi Covid-19, Cholilawati dan Dewi Suliyanthini (2020) dalam penelitiannya menemukan bahwa Pola perilaku konsumen telah berubah akibat pandemi Covid-19, terutama dalam hal mencari informasi tentang barang/jasa, pembelian barang/jasa, dan cara mereka menggunakan barang/jasa. Pencarian konsumen untuk informasi tentang lokasi, komoditas, dan layanan sebagian besar dilakukan sebelum epidemi Covid-19. Sementara itu, aktivitas konsumen dalam mencari informasi tentang tempat, komoditas, dan layanan selama pandemi Covid-19 cenderung berkurang. Kekhawatiran akan dampak dari wabah Covid-19 saat ini tentu saja telah menyebabkan perubahan kebiasaan perilaku pembelian masyarakat sebagai konsumen, terutama dalam melakukan pembelian secara online.

Perubahan tahapan keputusan pembelian, seperti: pengenalan masalah atau keinginan, pencarian informasi, penilaian pilihan alternatif, keputusan pembelian, dan perilaku pembelian, akan menyebabkan konsumen mengubah pola perilaku pembeliannya. Dengan datangnya 
kekhawatiran baru, seperti di era epidemi Covid-19 saat ini maka perilaku pembelian konsumen akan ikut berubah. (Christantyo et al, 2021).

Pemasar harus bisa menerapkan strategi yang jitu untuk memasarkan produk atau jasa mereka ke konsumen, sebagai upaya yang dapat digunakan untuk bertahan di tengah pandemi covid-19. Para pemasar dan pelaku bisnis diharuskan untuk bisa mengoptimalkan strategi pemasaran secara online dan digital branding sebagai salah satu bentuk sarana komunikasi dengan target konsumennya. Sebagai contohnya adalah seperti pada platform aplikasi Shopee, di mana aplikasi Shopee ini mengutamakan pemasaran online dengan memberikan banyak penawaran menarik kepada para konsumen ditengah masa pandemi Covid-19, seperti penawaran yang diberikan Shopee kepada para penggunanya adalah dengan menerapkan promosi gratis ongkos kirim(ongkir), yang di mana merupakan salah satu alasan mengapa konsumen lebih memilih aplikasi Shopee dibanding aplikasi serupa lainnya. Meski gratis ongkos kirim ini diberikan dengan batas pembelian tertentu dengan nominal yang tidak begitu besar, namun bagi calon konsumen, gratis ongkir merupakan suatu daya tarik yang memikat.

Berdasarkan uraian tersebut, maka akan dikaji lebih lanjut tentang bagaimana perbedaan perilaku konsumen dalam keputusan pembelian on line sebelum dan selama pandemi Covid-19

\section{METODE PENELITIAN}

Pendekatan penelitian yang digunakan yaitu penelitian deskriptif kuantitatif, adapun data yang digunakan adalah data Primer yakni data yang diperoleh dari jawaban responden terhadap kuesioner yang disebarkan kepada 100 orang responden, secara on line dan off line. Dalam penelitian ini menggunakan alat analisis Uji Statistik Paired Sample t-test.

Menurut Singgih Santoso (2018) Paired Sample t-Test merupakan pengujian yang dilakukan terhadap dua sampel berpasangan, dimana sampel berpasangan didefinisikan sebagai individu yang sama namun menerima dua perlakuan secara berbeda.Paired Sample t-Test adalah pengujian secara statistik yang melibatkan pengambilan dua pengukuran pada orang yang sama sebagai respons terhadap efek atau perlakuan tertentu. Pengukuran pertama dilakukan sebelum perlakuan tertentu diberikan, dan pengukuran kedua dilakukan setelahnya. Alasannya sederhana: jika perlakuan tidak berdampak, perbedaan rata-rata akan menjadi nol (Trihendradi C, 2012). Menurut Sugiyono (2011) rumus Paired Sample t-Test yang dapatdigunakanadalah sebagai berikut:

$$
\begin{aligned}
& t= \frac{\overline{x_{1}}-\overline{x_{2}}}{\sqrt{\frac{s_{12}}{n_{1}}+\frac{s_{2}}{n_{2}}-2 r\left(\frac{s_{1}}{\sqrt{n_{1}}}\right)\left(\frac{s_{2}}{\sqrt{n_{2}}}\right)}} \\
& \text { Keterangan: } \quad \bar{x}_{1}=\text { Rata-rata sampel } 1 \\
& \overline{x_{2}}=\text { Rata-rata sampel } 2 \\
& s_{1}=\text { Simpangan baku sampel 1 } \\
& s_{2}=\text { Simpangan baku sampel } 2 \\
& s_{1^{2}}=\text { Varians sampel 1 } \\
& s_{2^{2}}=\text { Varians sampel 2 } \\
& r \quad=\text { Korelasi antara dua sampel }
\end{aligned}
$$

\section{HASIL DAN PEMBAHASAN \\ Hasil Penelitian}

Menurut Singgih Santoso (2018) Paired Sample t-Test merupakan pengujian yang dilakukan terhadap dua sampel berpasangan, dimana sampel berpasangan didefinisikan sebagai individu yang sama namun menerima dua perlakuan secara berbeda. Paired Sample t-Test 
adalah pengujian secara statistik yang melibatkan pengambilan dua pengukuran pada orang yang sama sebagai respons terhadap efek atau perlakuan tertentu. Pengukuran pertama dilakukan sebelum perlakuan tertentu diberikan, dan pengukuran kedua dilakukan setelahnya. Alasannya sederhana: jika perlakuan tidak berdampak, perbedaan rata-rata akan menjadi nol. (Trihendradi C, 2012).

Pada uji Paired Sample t-Test menggunakan taraf signifikansi sebesar 5\%, adapun dasar pengambilan keputusan dalam uji Paired Sample t-Test adalah sebagai berikut :

1) Jika nilai propabilitas atau sig-2 tailed $<0,05$ maka terdapat perbedaan yang signifikan.

2) Jika nilai propabilitas atau sig-2 tailed $>0,05$ maka tidak terdapat perbedaan yang signifikan.

\section{A. Uji Paired Sample t-Test untuk Perilaku Konsumen}

Setelah melakukan pengujian normalitas variabel perilaku konsumen sebelum pandemi

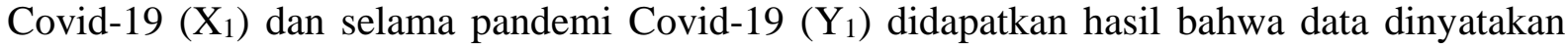
berdistibusi dengan normal, maka pengujian Paired Sample t-Testdapat dilakukan dengan menentukan hipotesis terlebih dahulu, adapun hipotesis untuk perilaku konsumen adalah sebagai berikut :

1. $\mathrm{H}_{0}$ : Diduga bahwa Tidak ada perbedaan perilaku konsumen sebelum dan selama pandemi Covid-19 pada pengguna Aplikasi Shopee di kota Makassar $\left(\mathrm{H}_{0}: \mu_{1}=\mu_{2}\right)$.

2. $\mathrm{H}_{1}$ : Diduga bahwa ada perbedaan perilaku konsumen sebelum dan selama pandemi Covid-19 pada pengguna Aplikasi Shopee di kota Makassar $\left(\mathrm{H}_{1}: \mu_{1} \neq \mu_{2}\right)$.

Untuk menguji Hipotesis diatas, berikut di paparkan hasil anlisis uji Paired Sample tTestberupa paired sample statistic, paired sample corelation, dan paired sample test (sig-2 tailed) Pada tabel dibawah ini :

\section{Tabel 3. Hasil Output Uji Paired Sample Statistic Perilaku Konsumen Sebelum dan Selama Pandemi covid-19}

\begin{tabular}{|l|c|c|c|c|}
\hline \multicolumn{5}{|c|}{ Paired Samples Statistics } \\
\hline & Mean & $\mathrm{N}$ & Std. Deviation & $\begin{array}{c}\text { Std. Error } \\
\text { Mean }\end{array}$ \\
\hline Sebelum Pandemi & 45.02 & 100 & 6.526 & .653 \\
\hline Selama Pandemi & 44.21 & 100 & 7.655 & .765 \\
\hline
\end{tabular}

Sumber : data diolah dengan SPSS, 2021

Hasil tabel 3 menunjukkan bahwa nilai rata-rata variabel perilaku konsumen sebelum pandemi $\left(\mathrm{X}_{1}\right)$ adalah sebesar 45.02 dan nilai rata-rata variabel perilaku konsumen selama pandemi ( $\left.\mathrm{Y}_{1}\right)$ adalah sebesar 44.21, hal tersebut menunjukkan bahwa secara rata-rata terjadi perbedaan perilaku konsumen dalam melakukan pembelian online sebelum dan selama pandemi Covid19.

\section{Tabel 4. Hasil Output Uji Paired Samples Correlations Perilaku Konsumen Sebelum dan Selama Pandemi Covid-19

\begin{tabular}{|c|c|c|c|}
\hline \multicolumn{4}{|c|}{ Paired Samples Correlations } \\
\hline & N & Correlation & Sig. \\
\hline $\begin{array}{c}\text { Sebelum Pandemi \& } \\
\text { Selama Pandemi }\end{array}$ & 100 & .854 & .000 \\
\hline
\end{tabular}

Sumber : data diolah dengan SPSS, 2021

Hasil pengujian Paired Samples Correlations menunjukkan bahwa nilai signifikansi 0.000, yang dimana nilai lebih kecil dari 0.05 , hal ini berarti bahwa antara perilaku konsumen sebelum dan selama pandemi Covid-19 memiliki hubungan yang signifikan. 
Tabel 5. Hasil Output Uji Paired Samples Test Perilaku Konsumen Sebelum dan Selama Pandemi Covid-19

\begin{tabular}{|c|c|c|c|c|c|c|c|c|}
\hline \multicolumn{9}{|c|}{ Paired Samples Test } \\
\hline & \multicolumn{5}{|c|}{ Paired Differences } & \multirow{3}{*}{$\mathrm{t}$} & \multirow{3}{*}{ df } & \multirow{3}{*}{$\begin{array}{l}\text { Sig. }(2 \\
\text { tailed) }\end{array}$} \\
\hline & \multirow[t]{2}{*}{ Mean } & \multirow[t]{2}{*}{$\begin{array}{l}\text { Std. } \\
\text { Deviati } \\
\text { on }\end{array}$} & \multirow[t]{2}{*}{$\begin{array}{l}\text { Std. } \\
\text { Error } \\
\text { Mean }\end{array}$} & \multicolumn{2}{|c|}{$\begin{array}{c}95 \% \text { Confidence } \\
\text { Interval of the } \\
\text { Difference }\end{array}$} & & & \\
\hline & & & & Lower & Upper & & & \\
\hline $\begin{array}{l}\text { Sebelum } \\
\text { Pandemi - } \\
\text { Selama } \\
\text { Pandemi }\end{array}$ & .810 & 3.987 & .399 & .019 & 1.601 & 2.032 & 99 & 0.045 \\
\hline
\end{tabular}

Sumber : data diolah dengan SPSS, 2021

Hasil uji t berupa Paired SampleTest menunjukkan bahwa nilai ssignifikan sebesar 0,045, yang berarti bahwa nilainya lebih kecil dari 0.05 , maka $\mathrm{H}_{0}$ ditolak. Hal ini berarti bahwa perilaku konsumen dalam melakukan pembelian online sebelum dan selama pandemi Covid-19, tidak sama. Dengan demikian dapat dikatakan bahwa terdapat perbedaan yang signifikan antara perilaku konsumen dalam pembelian online sebelum pandemi Covid-19 dengan perilaku konsumen dalam pembelian online selama pandemi Covid-19.

B. Uji Paired Sample t-Test untuk Keputusan Pembelian Online

Setelah melakukan pengujian normalitas variabel keputusan pembelian online sebelum pandemi covid-19 ( $\left.\mathrm{x}_{2}\right)$ dan selama pandemi covid-19 ( $\left.\mathrm{y}_{2}\right)$ didapatkan hasil bahwa data dinyatakan berdistibusi dengan normal, maka pengujian Paired Sample tTestdapat dilakukan dengan menentukan hipotesis terlebih dahulu, adapun hipotesis untuk perilaku konsumen adalah sebagai berikut:

1. $\mathrm{H}_{0}$ : Diduga bahwa Tidak ada perbedaan keputusan pembelian online sebelum dan selama pandemi covid-19 pada pengguna Aplikasi Shopee di kota Makassar $\left(\mathrm{H}_{0}\right.$ : $\left.\mu_{1}=\mu_{2}\right)$.

2. $\mathrm{H}_{1}$ : Diduga bahwa ada perbedaan keputusan pembelian online sebelum dan selama pandemi covid-19 pada pengguna Aplikasi Shopee di kota Makassar $\left(\mathrm{H}_{1}\right.$ : $\left.\mu_{1} \neq \mu_{2}\right)$.

Untuk menguji Hipotesis diatas berikut dipaparkan hasil anlisis uji Paired Sample t-Testberupa paired sample statistic, paired sample corelation, dan paired sample test (sig-2 tailed) Pada tabel dibawah ini :

Tabel 6. Hasil Output Uji Paired Samples Statistic Keputusan Pembelian On Line Sebelum dan Selama Covid -19

\begin{tabular}{|l|c|c|c|c|}
\hline \multicolumn{5}{|c|}{ Paired Samples Statistics } \\
\hline & Mean & $\mathrm{N}$ & Std. Deviation & $\begin{array}{c}\text { Std. Error } \\
\text { Mean }\end{array}$ \\
\hline Sebelum Pandemi & 27.78 & 100 & 3.933 & .393 \\
\hline Selama Pandemi & 27.54 & 100 & 4.084 & .408 \\
\hline
\end{tabular}

Sumber : data diolah dengan SPSS, 2021

Hasil tabel 6 di atas menunjukkan bahwa nilai rata-rata variabel keputusan pembelian online sebelum pandemi $\left(\mathrm{X}_{1}\right)$ adalah sebesar 27,78dan nilai rata-rata variabel perilaku konsumen selama pandemi $\left(\mathrm{Y}_{1}\right)$ adalah sebesar 27.54, hal ini menunjukkan bahwa secara rata-rata terjadi perbedaan keputusan pembelian online sebelum dan selama pandemi Covid-19. 
Tabel 7. Hasil Output Uji Paired Samples Correlation Keputusan Pembelian On Line Sebelum dan Selama Covid-19

\begin{tabular}{|c|c|c|c|}
\hline \multicolumn{4}{|c|}{ Paired Samples Correlations } \\
\hline & $\mathrm{N}$ & Correlation & Sig. \\
\hline $\begin{array}{c}\text { Sebelum Pandemi \& } \\
\text { Selama Pandemi }\end{array}$ & 100 & .879 & .000 \\
\hline
\end{tabular}

Sumber : data diolah dengan SPSS, 2021

Berdasarkan pada tabel 7 menunjukkan bahwa hasil pengujian Paired Samples Correlations nilai sig 0.000 , yang dimana nilai tesebut lebih kecil dari 0.05 , hal ini berarti bahwa antara perilaku konsumen sebelum dan selama pandemi Covid-19 memiliki hubungan yang signifikan.

\section{Tabel 8. Hasil Output Paired Samples Test Perilaku Keputusan Pembelian On Line Sebelum dan Selama Covid -19}

\begin{tabular}{|c|c|c|c|c|c|c|c|c|}
\hline \multicolumn{9}{|c|}{ Paired Samples Test } \\
\hline & \multicolumn{5}{|c|}{ Paired Differences } & \multirow{3}{*}{$\mathrm{t}$} & \multirow{3}{*}{ df } & \multirow{3}{*}{$\begin{array}{l}\text { Sig. } \\
(2- \\
\text { tailed })\end{array}$} \\
\hline & \multirow[t]{2}{*}{ Mean } & \multirow[t]{2}{*}{$\begin{array}{c}\text { Std. } \\
\text { Deviation }\end{array}$} & \multirow[t]{2}{*}{$\begin{array}{l}\text { Std. } \\
\text { Error } \\
\text { Mean }\end{array}$} & \multicolumn{2}{|c|}{$\begin{array}{c}95 \% \\
\text { Confidence } \\
\text { Interval of the } \\
\text { Difference }\end{array}$} & & & \\
\hline & & & & Lower & Upper & & & \\
\hline $\begin{array}{l}\text { Sebelum } \\
\text { Pandemi - } \\
\text { Selama } \\
\text { Pandemi }\end{array}$ & .240 & 1.987 & .188 & -.152 & 0.632 & 1.215 & 99 & 0.227 \\
\hline
\end{tabular}

Sumber : data diolah dengan SPSS, 2021

Hasil uji t berupa Paired Sample Test menunjukkan bahwa nilai signifikan sebesar 0,227, yang berarti bahwa nilainya lebih besar dari 0.05 , maka $\mathrm{H}_{1}$ ditolak. Hal ini berarti menunjukkan bahwa keputusan pembelian online sebelum dan selama pandemi Covid-19 dapat dikatakan bahwa tidak terdapat perbedaan yang signifikan antara keputusan pembelian online sebelum pandemi Covid-19 dengan perilaku konsumen dalam pembelian online selama pandemi Covid-19.

\section{Pembahasan}

\section{A. Perilaku Konsumen Sebelum dan Selama Pandemi Covid-19}

Kemajuan teknologi saat ini memberikan banyak pengaruh besar terhadap berbagai sektor, mulai dari sektor pendidikan, sektor kesehatan, dan tak terkecuali di sektor ekonomi khususnya dalam hal pemasaran, dimana di ketahui bahwa pemasaran kini bukan hanya berfokus pada sistem pemasaran secara konvensional akan tetapi telah beralih ke sistem pemasaran secara digital atau yang seringkali disebut sebagai digital marketing. Lalu terjadinya pandemi Covid-19, secara tidak langsung membuat konsumen bermigrasi dari pembelian konvensional ke pembelian secara online, terlebih setelah pemerintah melakukan pembatasan sosial, sehingga masyarakat harus mengerjakan berbagai aktivitas dari rumah.

Pengujian mengenai perilaku konsumen sebelum dan selama pandemi Covid-19 pada pengguna aplikasi Shopee dikota Makassar di dasarkan pada empat indikator yaitu: budaya, sosial, pribadi, dan psikologi. Berdasarkan hasil analisis data yang dilakukan di dapatkan bahwa perilaku konsumen sebelum dan selama pandemi Covid-19 pada pengguna aplikasi Shopee di kota Makassar dalam melakukan pembelian online mengalami perbedaan yang signifikan. Hal tersedut di dasari oleh hasil uji Paired Sample 
$t$-Test, ditemukan nilai signifikan sebesar 0.045 dan lebih kecil dari 0.05 , hal tersebut menunjukkan bahwa ada perbedaan perilaku konsumen sebelum dan selama pandemi Covid-19.

Hasil pengujian yang telah dilakukan, sejalan dengan hipotesis yang telah diajukan dalam penelitian ini, hipotesi mengenai adanya perbedaan perilaku konsumen sebelum dan selama pandemi Covid-19 pada pengguna aplikasi Shopee telah dibuktikan di dalam hasil analisis data yang telah dilakukan. Adanya perbedaan perilaku konsumen yang signifikan sebelum dan selama pandemi Covid-19 menunjukkan bahwa pandemi Covid-19 berpengaruh terhadap pola perilaku konsumen. Perubahan pola perilaku yang terjadi dimasa pandemi Covid-19 sejalan dengan teori yang menyatakan bahwa Perubahan tahapan pembelian, seperti: pengenalan masalah atau keinginan, pencarian informasi, penilaian pilihan alternatif, keputusan pembelian, dan perilaku pembelian, akan menyebabkan konsumen mengubah pola perilaku pembeliannya. Dengan datangnya kekhawatiran baru, seperti di era epidemi Covid-19 saat ini maka perilaku pembelian konsumen akan ikut berubah. (Christantyo et al, 2021).

Menurut hasil penelitian yang dilakukan, perbedaan perilaku konsumen sebelum dan selama pandemi Covid-19 di dasari oleh :

1) Perilaku konsumen sebelum dan selama pandemi berdasarkan pada faktor budaya, yang dimana menurut hasil penelitian di dapatkan bahwa pola perilaku konsumen pada faktor budaya mengalami perubahan terkait hal bagaimana konsumen (dalam hal ini pengguna aplikasi Shopee di kota Makassar) melakukan kebiasaan pembelian secara online, dimana pola perilaku konsumen sebelum pandemi covid-19 cenderung melakukan pembelian secara konvensional sedangkan pola perilaku konsumen selama pandemi Covid-19 cenderung mendorong konsumen memilih untuk melakukan pembelian secara online, hal ini disebabkan karena pengaruh pandemi Covid-19 dan kebijakan pemerintah yang memberlakukan pembatasan sosial, sehingga mobilitas konsumen untuk melakukan pembelian secara konvensional akan cenderung terbatas, dan akhirnya konsumen mimilih membiasakan diri untuk melakukan pembelian secara online. Hasil penelitian ini sejalan dengan penelitian terdahulu yang menemukan bahwa perilaku konsumen pada masa pandemi Covid19 menurunkan tingkat konsumsi masyarakat yang dipengaruhi oleh tingkat finansial dan kemudian menimbulkan perilaku konsumen yang sebelumnya jarang dilakukan oleh masyarakat, seperti halnya melakukan pembelian online yang di jadikan suatu kebiasaan dimasa pandemi Covid-19 (Rohmah, 2020).

2) Perilaku konsumen sebelum dan selama pandemi Covid-19 di dasarkan pada faktor sosial. Ada perbedaan yang terjadi dalam perilaku konsumen menentukan pilihannya. Perilaku konsumen dimasa sebelum pandemi Covid-19 tidak terlalu banyak melibatkan peranan keluarga dalam menentukan pilihan saat melakukan pembelian online, sedangkan selama pandemi Covid-19, konsumen akan cenderung meminta rekomendasi dari keluarga dalam melakukan pembelian secara online, hal ini terjadi karena banyaknya waktu yang dihabiskkan oleh konsumen bersama dengan keluarga di rumah selama masa pandemi Covid-19. Hasil penelitian ini sejalan dengan penelitian terdahulu yang menemukan bahwa peranan sosial dalam hal ini lingkungan keluarga menentukan perilaku seorang individu dalam bertindak terlebih di situasi pandemi Covid-19 (Silalahi dan Purba, 2021).

3) Perilaku konsumen sebelum dan selama pandemi Covid-19 di dasarkan pada faktor pribadi. Menurut hasil penelitian yang dilakukan menujukkan bahwa perubahan pola perilaku konsumen pada indikator pribadi berkaitan dengan gaya hidup konsumen. Sebelum pandemi Covid-19 gaya hidup masyarakat cenderung tidak dibatasi, berbeda dengan gaya hidup masyarakat selama pandemi Covid-19 dimana masyarakat diwajibkan oleh pemerintah untuk menerapkan protokol kesehatan (gaya 
hidup sehat) seperti memakai masker, mejaga jarak dan menjauhi kerumunan, hal tersebut tentu ikut membuat terjadinya perubahan terhadap pola perilaku konsumen dan di satu sisi setiap individu harus tetap memenuhi kebutuhan hidup. Teori social judgement process menyatakan bahwa perubahan sikap individu terhadap objek sosial yang terkait dengan suatu masalah tertentu sebagai akibat dari pertimbangan internal yang memunculkan tiga zona yaitu zona penerimaan (latitude of acceptance), zona penerimaan, dan zona penerimaan. penolakan (latitude ofrejection), dan zona tanpa komitmen (latitude of no commitment), yang semuanya dipengaruhi oleh Ego Involvement. Adanya objek sosial berupa kepedulian seperti pandemi Covid-19 menggambarkan pesan tersebut. Dalam skenario ini, keterlibatan Ego Involvement dalam bentuk menjaga diri, yang menekan penularan Covid-19. Preferensi konsumen untuk melakukan pembelian online dibandingkan transaksi konvensional menunjukkan bahwa mereka berada di zona penerimaan (latitude of acceptance), yang berarti mereka menerima pesan atau informasi tentang pandemi Covid-19.

4) Perilaku konsumen sebelum dan selama pandemi Covid-19 di dasarkan pada faktor psikologi. Berdasarkan hasil penelitian yang dilakukan di dapatkan bahwa pembelian secara online dianggap menjadi alternatif utama yang dipilih oleh konsumen karena dapat lebih memudahkan konsumen (dalam hal ini pengguna aplikasi Shopee dikota Makassar) terlebih dimasa selama pandemi Covid-19, adanya kemudahan dalam melakukan pembelian secara online secara tidak langsung menjadi motivasi bagi para konsumen untuk terus melakukan pembelian secara online, selain itu konsumen cenderung memiliki persepsi yang baik terhadap aplikasi belanja online. Hasil penelitian ini juga sejalan dengan teori yang dikemukakan oleh Amijaya (dalam Nurrahmanto, 2015) yang menyatakan bahwa Ketika konsumen merasa mudah untuk berinteraksi dengan situs e-commerce dalam hal memperoleh informasi produk, membeli barang, dan melakukan pembayaran, mereka cenderung mempertimbangkan dan menggunakan aplikasi pembelian online. Hasil penelitian ini juga sejalan dengan studi yang dilakukan dilakukan oleh Martinus Robert Haruk yang menemukan bahwa psikologis berpengaruh positif dan signifikan terhadap keputusan pembelian pada masyarakat di masa pandemi Covid-19.

\section{B. Keputusan Pembelian Online Sebelum dan Selama Pandemi Covid-19}

Pengujian keputusan pembelian online pada pengguna aplikasi Shopee di kota Makassar sebelum dan selama pandemi Covid-19, didasarkan pada enam indikator yaitu : jenis produk, waktu pembelian, merek, bentuk produk, cara pembayaran, dan kualitas produk. Berdasarkan hasil analisis data di dapatkan bahwa keputusan pembelian online sebelum dan selama pandemi Covid-19 pada pengguna aplikasi Shopee di kota Makassar tidak mengalami perbedaan yang signifikan.Hal tersebut di dasari hasil uji Paired Sample $t$-Test, ditemukannilai sebesar 0.227 dan lebih besar dari 0.05 , hal tersebut menunjukkan bahwa pandemi covid-19 tidak berpengaruh terhadap keputusan pembelian secara online karena tidak adanya perbedaan keputusan pembelian sebelum dan selama pandemi Covid19.

Hasil pengujian yang telah dilakukan, sejalan dengan hipotesis yang telah diajukan dalam penelitian ini. Hipotesis mengenai adanya perbedaan perilaku konsumen sebelum dan selama pandemi Covid-19 pada pengguna aplikasi Shopee telah dibuktikan di dalam hasil analisis data yang dilakukan, hasil penelitian ini juga sejalan dengan hipotesis yang diajukan oleh peneliti mengenai keputusan pembelian pada pengguna aplikasi Shopee di kota Makassar sebelum dan selama pandemi Covid-19, di dapatkan bahwa tidak ada perbedaan yang signifikan antara keputusan pembelian sebelum pandemi dangan keputusan pembelian selama pandemi Covid-19. 
Tidak terjadinya perbedaan yang signifikan antara keputusan pembelian secara online sebelum dan selama pandemi Covid-19 menunjukkan bahwa tidak adanya pengaruh pandemi Covid-19 secara signifikan terhadap keputusan pembelian secara online yang dilakukan oleh pengguna aplikasi Shopee dikota Makassar, konsumen cenderung akan memutuskan untuk melakukan pembelian online terlebih saat ini telah memasuki era digitalisasi, pembelian secara online dirasa lebih memudahkan konsumen, sehingga keputusan pembelian secara online tidak begitu dipengaruhi oleh pandemi Covid-19, terbukti sejak sebelum pandemi Covid-19 sudah banyak konsumen yang memutuskan untuk beralih dari pembelian secara konvensional ke pembelian secara online.

Keputusan pembelian secara online bukan saja terjadi disaat situasi pandemi Covid-19, banyak konsumen (dalam hal ini pengguna aplikasi Shopee di kota Makassar) yang telah memutuskan untuk beralih dari pembelian secara konvensional menuju ke pembelian secara online, hal yang membuat konsumen memutuskan untuk melakukan pembelian secara online antara lain adalah:

1) Jenis produk yang ditawarkan pada aplikasi online sangat beragam, beragamnya produk yang ditawarkan tersebut membuat konsumen tertarik untuk melakuakan pembelian secara online.

2) Pembelian secara online dapat dilakukan kapan dan dimana saja, konsumen merasa dimudahkan karena kegiatan pembelian secara online dapat dilakukan kapan dan dimana saja, hal tersebut membuat masyarakat cenderung lebih memilih untuk melakukan pembelian secara online dibandingkan dengan pembelian secara konvensional.

3) Kemudahan menemukan produk dengan merek yang disukai juga menjadi pemicu mengapa konsumen memutuskan untuk melakukan pembelian secara online.

4) Metode pembayaran yang ditawarkan pada aplikasi pembelian online (Shopee) relatif lebih banyak, sehingga hal tersebut membuat konsumen tertarik untuk melakukan pembelian secara online.

5) Konsumen mengaku puas terhadap pembelian sebelumnya, konsumen pada pengguna aplikasi Shopee di kota Makassar mengaku telah puas melakukan pembelian secara online, sehingga kedapannya mereka akan tetap memiih untuk melakukan pembelian secara online.

\section{KESIMPULAN}

Berdasarkan hasil analisis yang telah dilakukan, maka dapat ditarik kesimpulan bahwa:

1) Berdasarkan hasil analisis mengenai perilaku konsumen sebelum dan selama pandemi Covid-19 diperoleh hasil bahwa ada perbedaan perilaku konsumen secara signifikan sebelum dan selama pandemi Covid-19, sehingga dapat dinyatakan pandemi Covid-19 berpengaruh terhadap perubahan pola perilaku konsumen.

2) Berdasarkan hasil analisis mengenai perbedaan keputusan pembelian secara online sebelum dan selama pandemi Covid-19 diperoleh hasil bahwa tidak adanya perbedaan keputusan pembeliansebelum dan selama pandemi Covid-19, sehingga dapat dinyatakan pandemi Covid-19 tidak berpengaruh terhadap keputusan pembelian secara online.

3) Hasil analisis menunjukkan bahwa pandemi Covid-19 berpengaruh terhadap perubahan pola perilaku konsumen, tetapi tidak mempengaruhi konsumen dalam mengambil keputusan pembelian secara online.

\section{DAFTAR PUSTAKA}

Amanah, D. (2018). Perilaku Belanja Online Di Indonesia: Studi Kasus. September. https://doi.org/10.21009/JRMSI.009.2.02.

Amirullah. (2015). Populasi dan sampel (pemahaman, jenis dan teknik).

Badan Pusat Statistik. (2021). Kota Makassar 
Bertuah, Eka Dan Wicaksono, Satrio Multi (2021). Perbandingan Perilaku Belanja Online Melalui Shopee Dan Tokopedia Di Masa Pandemi covid-19.

Buana, Dana Riska. (2020). Analisis Perilaku Masyarakat Indonesia dalam Menghadapi Pandemi Virus Corona ( covid-19) dan Kiat Menjaga Kesejahteraan Jiwa Analisis Perilaku Masyarakat Indonesia dalam Menghadapi Pandemi Virus.https://doi.org/10.15408/sjsbs.v7i3.15082

Burhanuddin, Nurkholifah. (2018). Pengaruh keragaman produk dan free shipping terhadap keputusan pembelian konsumen pada situs jual beli onlineShopee di kota Makassar.

Cholilawati dan Suliyanthini, Dewi. (2020). Perubahan Perilaku Konsumen Selama Pandemi Covid-19.

Christantyo, Hartojo et al, (2021). Faktor-Fakto ryang Mempengaruhi Perubahan Perilaku Pasien Kanker Dan Daya Belinya Selama Masa Pandemi Terhadap Obat Kemoterapi, Dan Pola Pomosi (Suatu Kajian Studi Literatur Manajemen Pemasaran).

Fajri, (2019). Comparative Perilaku Konsumen Dalam Perspektif Ekonomi Konvensional Dan Syariah. Jurnal PPKn \& Hukum, 14(2), 123-135.

Firmansyah, Anang M. (2012). Perilaku Konsumen (sikap dan pemasaran). Yogyakarta: CV. Budi UtamaIkranegara.

Ginting, Nembah F. Hartimbul (2015). Manajemen Pemasaran. Bandung: CV Yrama Widya.

Hanum, Zubaidah. (2017). Faktor - faktor yang mempengaruhi perilaku konsumen dalam keputusan pembelian sepatu merek nike di kota medan. 06, 37-43.

Hasan. (2019). Jieb :Jurnal Ilmiah Ekonomi Bisnis (S4), 5(November), 77-87.

Hutauruk Martinus Robert.(2020). Pengaruh Pandemi Covid-19 terhadap faktor yang menentukan Perilaku Konsumen untuk membeli barang kebutuhan pokok di Kota Samarinda.

Indartini, (2012). Analisis terhadap perilaku konsumen dalam berbelanja secara online di kotamadya madiun. 37-51.

Kotler, P. (2013). Manajemen Pemasaran. Jakarta: Erlangga.

Kotler, Philip dan Amstrong, Gary. (2016). Principles of Marketing, 15th Pearson Education Limited

Malau, Harman. (2017). Manajemen Pemasaran. Alfabeta: Bandung.

Manossoh, Angelina et al. (2015). Analisis perbandingan sikap konsumen terhadap penggunaan produk shampoo clear dan shampoo pantene di winangun. 3(3), 74-80.

Prasetyo, Dwi. (2019). Perbedaan Sikap Konsumen Dalam Menambil Keputusan Pembelian Sebelum Dan Sesudah Lebaran Di Pasar Medern Kecamatan Seberang Ulu Palembang.

Putri, rika dwiana. (2020) Perbandingan Kekuatan Uji Metode Kolmogorov-Smirniv, Anderson-Darling, Dan Shapiro-Wilk Untuk Menguji Normlitas Data.

Rahmawati, S. A. (2013). Antecedent Keputusan Pembelian ( Studi Kasus Online Purchasing)

Rohmah, Ainur (2020). Pandemi covid-19 dan dampaknya terhadap perilaku konsumen di Indonesia, Surabaya: Jurnal Inovasi Penelitaian

Silalahi, Rudi Yanto Batara \& Purba, Martuahman Parlindungan (2021). Online shopping consumer behavior during covid-19 pandemic. Jurnal Ilmiah Manajemen

Sugiyono. 2011. Metodologi Penelitian Kuantitatif, Kualitatif, dan R\&D. Bandung: Alfabeta $\mathrm{CV}$.

Sumarwan. (2014). Model Keputusan Konsumen. In Perilaku konsumen (1st ed., pp. 1- 41). Universitas Terbuka.

Sungadji dan Sopiah, (2013), Perilaku Konsumen,Cetakan Pertama,Yogyakarta: CV. Andi Offset.

Swastha., \& Irawan. (2013). Manajemen Pemasaran Modern. Yogyakarta: Penerbit Liberty.

Tjiptono, Fandydan Anastasia Diana. (2020). Pemasaran. Yogyakrta: CV Andi Offset.

Trihendradi. (2013). Langkah Mudah Menguasai SPSS 21, Yogyakarta: Andi Offset. 
Ulina, Nusan. (2015). Analisis Perbandingan Keputusan Pembelian Complex Buying Behaviour Pada Konsumen Perumahan Sari Residence (Kelas Atas) Dan Perumahan Wijaya Kusuma (Kelas Menengah).

Ummasyroh,. Firdaus, Yusnizal,. dan Andriyani, Titi. (2020). Penerapan Marketing 4.0 Dan Pengaruhnya Terhadap Keberhasilan Kegiatan Promosi Pemasaran Politeknik Negeri Sriwijaya. Jurnal Riset Terapan Akuntansi, Vol.4 No.1, 2020

Veronika, S. (2013). Motivation of Online Buyer Behavior. Journal of Competitiveness, 5(3), 14-30. https://doi.org/10.7441/joc.2013.03.02.

Yacub, Rudi \& Mustajab, Wahyu. (2020). Analisis Pengaruh Pemasaran Digital (Digital Marketing) Terhadap Brand Awareness Pada E-commerce. Manajerial, Vol. 12 No.2 Juni 2020, Hal - 198 http://ejournal.upi.edu/index.php/manajerial/. 